\title{
Penumbuhan Silikon Nanowire dengan Nanokatalis Perak menggunakan Metode HWC-In Plasma-VHF-PECVD melalui Optimasi Tekanan
}

\author{
Diky Anggoro $^{1, *}$ dan Toto Winata ${ }^{2}$ \\ ${ }^{1}$ Jurusan Fisika-FMIPA, Institut Teknologi Sepuluh Nopember, \\ Kampus ITS Sukolilo, Surabaya 61111 \\ ${ }^{2}$ Jurusan Fisika-FMIPA, Institut Teknologi Bandung, \\ Jl. Ganesha No. 10, Bandung 40132
}

\begin{abstract}
Intisari
Penelitian mengenai penumbuhan silikon nanowire (SiNW) telah dilakukan dengan mengunakan metode Plasma Enhanced Chemical Vapour Deposition (PECVD). Katalis yang digunakan yaitu logam perak (Ag). Penggunaan nano katalis perak dalam penelitian ini dibatasi seberat 0,025 gram. Nanokatalis perak tersebut dideposisi pada substrat gelas dengan cara evaporasi dalam keadaan vakum untuk membentuk lapisan tipis Ag pada substrat. Hasil penumbuhan nanokatalis dilakukan karakterisasi SEM dan EDX dengan hasil logam perak yang di-annealing selama satu jam menghasilkan pulau-pulau Ag berukuran dominan 70-80 nm. Ag yang di-annealing selama satu jam kemudian digunakan untuk penumbuhan silikon nanowire. Sebagai gas carier digunakan gas silant $\mathrm{SiH}_{4}$ dengan precursor silikon dengan kecepatan alir $70 \mathrm{sccm}$ dan daya rf 8 watt. Variasi optimasi dilakukan pada parameter tekanan 100, 200, 300 dan 400 mTorr. SEM dan EDX dilakukan untuk mengkarakterisasi silikon nanowire. Dari hasil SEM dan EDX, tekanan deposisi 100 mTorr dapat menghasilkan silikon nanowire dengan rasio penumbuhan yang tinggi. Diameter silikon nanowire diperoleh 70-120 nm dan panjang silikon nanowire $200-5000 \mathrm{~nm}$.
\end{abstract}

\begin{abstract}
Research on silicon nanowire (SiNW) growth has been performed by using Plasma Enhanced Chemical Vapour Deposition (PECVD). The catalyst used is metallic silver (Ag). The use of silver in the study nanokatalis capped at 0.025 grams. Nanocatalys silver in the deposition on glass substrates by evaporation in a vacuum to form a thin film on a substrate Ag. Theresults nanocatalyst growth characterization by SEM and EDX results in metallic silver-annealing for one hour produces Ag islands 30-110 nm sized. Ag that are annealed for one hour and then used for silicon nanowire growth. As the carrier gas used $\mathrm{SiH}_{4}$ silane gas with silica precursor flow rate $70 \mathrm{sccm}$ and $\mathrm{rf}$ power of 8 watts. Variations in pressure parameters optimization is done at 100, 200, 300 and 400 mTorr. SEM and EDX performed to characterize the silicon nanowire. From the results of SEM and EDX, deposition pressure of 100 mTorr to produce silicon nanowire with a high ratio. Diameter silicon nanowire obtained 70-120 nm and a length of silicon nanowire 200-5000 nm.
\end{abstract}

KATA KUNCI: Ag, SiNW, HWC-in plasma-VHF-PECVD

\section{PENDAHULUAN}

Nanowire memiliki definisi padatan silinder yang memanjang seperti kawat namun berdiameter kurang dari sepuluh nanometer hingga ratusan nanometer dan memiliki panjang hingga orde mikro meter. Berbagai penelitian telah menunjukkan bahwa penumbuhan SiNW dapat dilakukan dengan berbagai metode. Secara umum, penumbuhan material berskala nano dapat dibagi ke dalam dua pendekatan, yaitu

\footnotetext{
*E-MAIL: anggoro@physics.its.ac.id
}

pendekatan top-dow dan pendekatan bottom-up [1]. Pada pendekatan top-down partikel material berukuran besar dipecah menjadi partikel berukuran nano. Penumbuhan top-down ini yaitu metode litografi dan berbagai modifikasinya (misalnya optical lithography, X-ray lithography dip pen nanolithography, electron beam lithography, dan nanoimprint lithography)[2]. Salah satu kekurangan pendekatan top-down ini yaitu kecenderungan cacat pada struktur kristal dan struktur permukaannya lebih besar dibandingkan dengan pendekatan bottom-up. Pendekatan kedua yaitu pendekatan bottom-up $[3,4]$. Pada pendekatan ini atom-atom, molekul-molekul, atau kluster-kluster digabung membentuk partikel berukuran nano yang dikehendaki. Berbagai jenis metode penumbuhan 
termasuk ke dalam pendekatan bottom-up ini, misalnya yaitu metode PVD (Physical Vapor Deposition) dan CVD (Chemical Vapor Deposition). Salah satu jenis penumbuhan CVD yaitu metode PECVD, yakni penumbuhan material berskala nano yang dapat dilakukan pada temperatur yang lebih rendah dibandingkan metode CVD pada umumnya sehingga jenis substrat yang dapat digunakan pada metode ini juga lebih bervariasi $[5,6]$.

Salah satu material yang sering dikembangkan sebagai material nanowire yaitu silikon dan sering dikenal dengan silikon nanowire (SiNW). Silikon nanowire memiliki properti atau karakteristik yang berbeda dengan silikon bulk [1]. Salah satunya yaitu celah pita energi silikon nanowire dapat diatur dengan mengatur diameter nanowire yang ditumbuhkan telah melakukan penelitian bahwa lebar celah pita energi akan bertambah dengan berkurangnya diameter silikon nanowire [1]. Silikon nanowire merupakan salah satu jenis nanowire yang bersifat semikonduktor dan memiliki karakteristik berbeda dengan karakteristik material pada umumnya. Dengan struktur diperkecil pada silicon nanowire serta struktur kristal yang homogen, silikon nanowire dapat bersifat sebagai bahan semikonduktor yang memiliki sifat setengah logam sehingga silikon nanowire memiliki berbagai macam sifat elekronik seperti sifat elektronik yang terdapat pada Carbon Nanotube [7, 8].

\section{Katalis}

Silikon nanowire yang ditumbuhkan dengan mekanisme Vapor-Liquid-Solid (VLS) biasanya digunakan katalis berupa butiran berukuran nano dan berfungsi sebagai pemandu dalam penumbuhan silikon nanowire. Lapisan logam katalis ditumbuhkan pada substrat setipis mungkin, agar pada saat proses annealing dihasilkan butiran-butiran berdiameter hingga beberapa puluh nanometer. Diameter butiran logam katalis inilah yang nantinya menentukan diameter silikon nanowire yang tumbuh. Selain itu, butiran logam katalis ini nantinya juga merepresentasikan susunan, kerapatan, serta distribusi ukuran [9].

\section{Mekanisme Penumbuhan SiNW}

Metode PECVD merupakan salah satu metode yang umum digunakan dalam penumbuhan material berukuran nanometer. Dilaporkan bahwa berbagai material dapat ditumbuhkan dengan metode ini misalnya, CNT (carbon nanotubes), grafen, dan SiNW (silicon nanowires)[9]. Dengan metode PECVD, material berukuran nanometer dapat ditumbuhkan pada temperatur yang relatif rendah dibandingkan dengan metode penumbuhan lainnya. Metode PECVD ini secara umum merupakan metode yang sederhana, tetapi dengan proses-proses fisika dan kimia yang cukup kompleks [6]. Hal tersebut karena banyaknya reaksi yang terlibat dalam prosesnya, sehingga relatif sulit mengidentifikasi jenis reaksi yang dominan dalam proses penumbuhan. Sesuai dengan namanya, pada metode PECVD ini plasma merupakan hal paling penting karena dari plasma yang dihasilkan inilah nantinya material dengan sifat-sifat yang diinginkan dapat diperoleh.

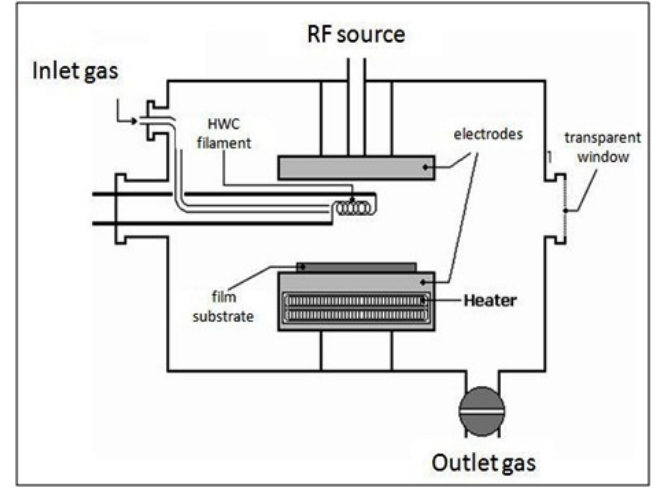

Gambar 1: Skema HWC-in plasma-VHF-PECVD [10].

Elektron-elektron yang senantiasa diakselarasi oleh medan listrik selama proses penumbuhan akan menumbuk gas dan menyebabkan terjadinya ionisasi. Energi elektron rata-rata yang menumbuk molekul-molekul gas adalah:

$$
\epsilon=e E \lambda_{e}
$$

dengan e adalah muatan elektron, E medan listrik yang diberikan, $\lambda_{e}$ adalah jalan bebas rata-rata elektron Dari persamaan tersebut dapat dilihat bahwa pada tekanan deposisi yang tinggi, $\lambda_{e}$ akan mengecil, maka medan listrik harus dinaikkan agar proses ionisasi tetap terjadi dan plasma dapat dipertahankan. Pengembangan teknik PECVD terakhir yang berhasil dikembangkan oleh KK Fismatel ITB adalah teknik HWC-in plasma-VHF-PECVD (skema ditunjukkan Gambar 1). Teknik ini digunakan untuk menumbuhkan SiNW. Perbedaan utama dengan teknik PECVD konvensional yaitu adanya kumparan filamen pemanas dan radio frequency yang sangat tinggi yaitu $70 \mathrm{MHz}$.

\section{METODOLOGI PENELITIAN}

Secara garis besar pada penelitian ini dilakukan studi untuk menentukan parameter yang optimal untuk penumbuhan silikon nanowire dengan variasi parameter tekanan gas didalam chamber. Penumbuhan silikon nanowire ditumbuhkan pada nano katalis perak. Nano katalis perak tersebut ditumbuhkan oleh metode evaporasi dengan pembatasan massa perak di uapkan hingga habis terdeposisikan pada gelas objek di Laboratorium MOCVD. Kemudian lapisan katalis yang telah terdeposisi pada substrat dilakukan annealing annealing menggunakan furnace. Setelah katalis terbentuk pada substrat barulah dilakukan penumbuhan silikon nanowire dengan menggunakan metode HWC-in plasma-VHF-PECVD, dengan parameter deposisi, laju aliran gas $800 \mathrm{sccm}$, temperatur substrat $380^{\circ} \mathrm{C}$, temperatur filamen $800^{\circ} \mathrm{C}$, waktu deposisi 60 menit, frekuensi $700 \mathrm{MHz}$ (rf), daya rf yang rendah 80 watt. Optimasi yang dilakukan dengan variasi tekanan chamber 100 hingga 400 mTorr.

Karakterisasi SEM (JEOL seri JSM-6510/LV/A/LA) dilakukan pada setiap sampel lapisan tipis Ag yang telah diannealing dan lapisan tipis SiNW. Tujuan dilakukan karakte- 


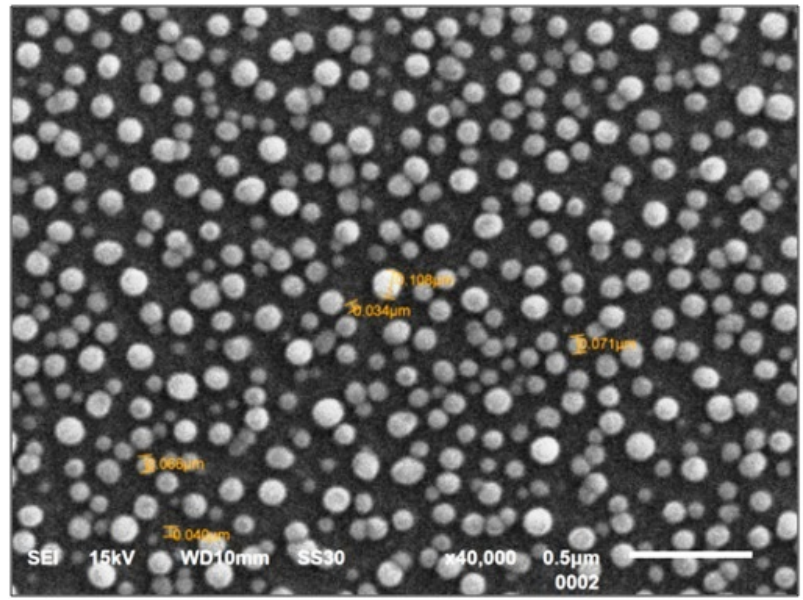

(a)

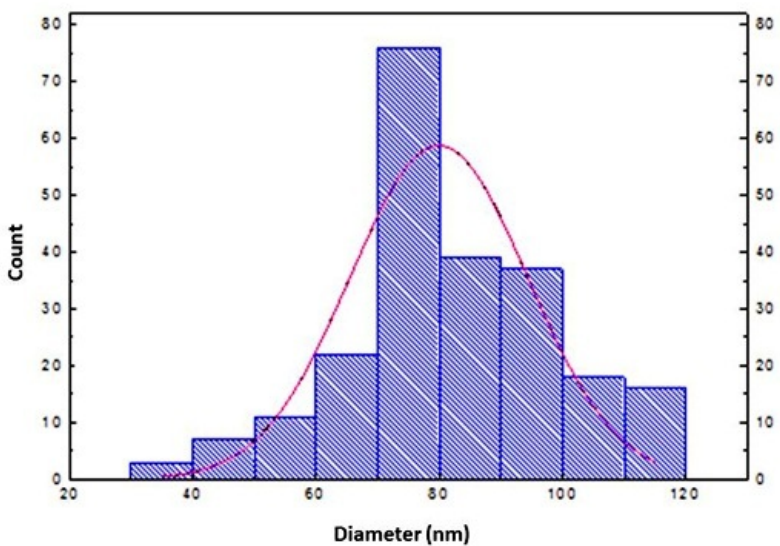

(b)

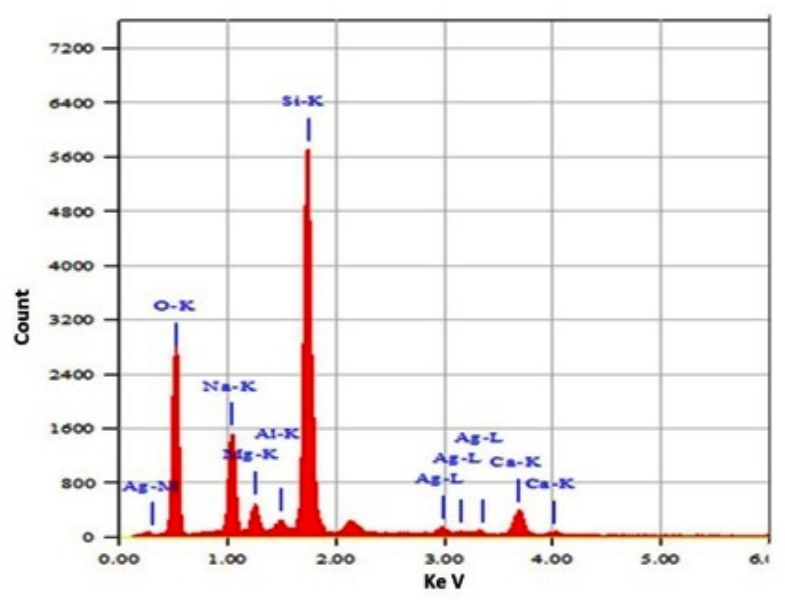

(c)

Gambar 2: (a) citra SEM Ag yang di-annealing 1 jam dan distribusi diameter nano-island, (b) grafik distribusi diameter nano-island, dan (c) hasil spektrum EDX dari katalis Ag.

risasi ini yaitu untuk mengetahui morfologi, diameter butiranbutiran Ag dan panjang serta diameter silikon nanowire. Untuk mendapatkan citra SEM silikon nanowire, SEM dilakukan pada penampang melintang ditengah sampel dengan tujuan agar diketahui panjang silikon nanowire yang tumbuh. Sebuah SEM bekerja seperti halnya mikroskop optis, namun SEM menggunakan penembak elektron medan emisi sebagai sumber cahaya dengan energi 1-20 KeV [10].

\section{HASIL DAN PEMBAHASAN}

\section{Penumbuhan Nanokatalis Ag}

Sebanyak 0,0025 gram perak ditumbuhkan di atas subtrat gelas objek dengan metode evaporasi. Lapisan tipis Ag kemudian di-annealing pada suhu $400^{\circ} \mathrm{C}$ selama 1 dan 2 jam. Lapisan Ag yang telah di-annealing dikarakterisasi SEM dan EDX.
Ukuran diameter pulau-pulau Ag yang terbentuk setelah dianneling selama 1 jam relatif seragam. Dari hasil SEM, dapat dibuat histogram dan kurva distribusinya. Diameter tiap island diukur dalam skala pixel kemudian dikonversi ke ukuran nano. Histogram dibuat dalam Origin Pro 8.0. Pengelompokan ukuran butiran dihitung secara otomatis oleh Origin. Distribusi yang digunakan yaitu distribusi Gauss atau distribusi normal dengan rata-rata ukuran diameter island $\mathrm{Ag}$ yang terbentuk 70-80 nm, seperti terlihat pada Gambar 2, serta diperoleh pula hasil karakterisasi katalis Ag menggunakan EDX, dengan komposisi Ag 2,78\%.

\section{Penumbuhan SiNW dengan metode HWC-in plasma-VHF-PECVD}

Pada penelitian ini konfigurasi PECVD yang digunakan yaitu konfigurasi HWC in plasma-VHF-PECVD. Pada konfigurasi ini hot wire cell atau filamen berbentuk spiral terletak antara dua elektroda. Penempatan hot wire cell ini yaitu sejajar dengan saluran gas masukan. Hal ini bertu- 


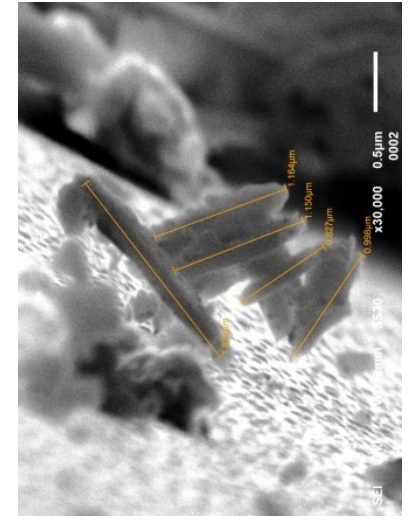

(a)

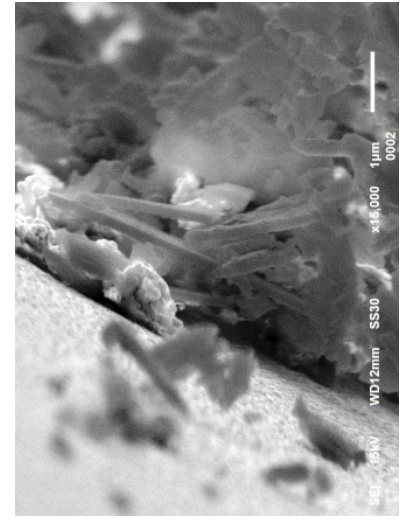

(b)

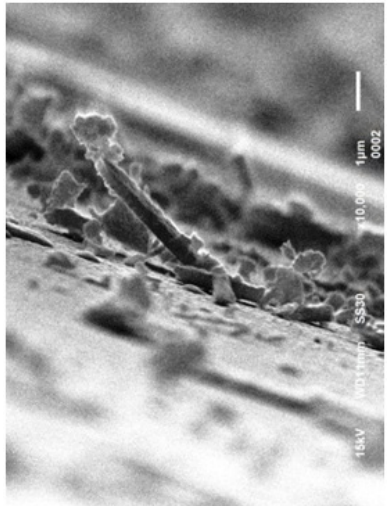

(a)

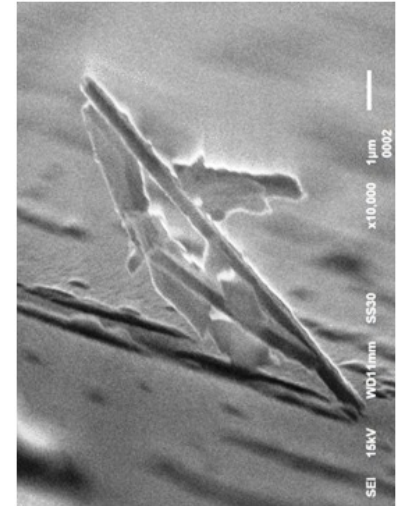

(b)
Gambar 3: (a) dan (b) adalah Citra SEM penampang melintang SiNW/Ag yang sama, serta penumbuhan pada tekanan 100 mTorr dengan titik fokus pengambilan citra yang berbeda.

juan agar gas memasuki lingkaran kawat spiral (hot wire cell) dan mengalami deposisi lebih efektif pada kumparan filamen ini. Dua buah elektroda (anoda dan katoda) ditelakkan sejajar dalam chamber. Anoda dihubungkan dengan sumber daya rf sedang-kan katoda dihubungkan dengan ground sebagai elektroda negatif. Substrat diletakkan di atas katoda sedangkan sistem pemanas substrat ditempatkan dalam katoda. Elektronelektron yang berasal dari katoda kemudian dipercepat oleh medan listrik menumbuk molekul-molekul gas sehingga akan terurai menjadi radikal-radikal reaktif dan berpijar.

\section{Penumbuhan SiNW pada tekanan 100 mTorr}

Pada tekanan 100 mTorr sangat efektif menghasilkan silikon nanowire karena elektron mempunyai energi yang cukup untuk bertumbukan terlihat pada Gambar 3, telah berhasil ditumbuhkan silikon nanowire dengan ukuran diameter 70-120 nm, hasil dari pengukuran langsung citra SEM yang diperoleh dan panjang nanowire tersebut berkisar antara $200 \mathrm{~nm}$ hingga $5000 \mathrm{~nm}$.

Fungsi energi dalam plasma adalah menggantikan energi panas sehingga energi plasma dapat membantu pemisahan atau pemecahan molekul gas $\mathrm{SiH}_{4}$ dan membentuk silikon nanowire. Sedangkan fungsi dari medan listrik dalam plasma adalah untuk meluruskan silikon nanowire agar tumbuh tegak lurus vertikal terhadap permukaan substrat.

\section{Penumbuhan SiNW pada tekanan 200 mTorr}

Penumbuhan SiNW selanjutnya dilakukan pada tekanan 200 mTorr. Pada daya rendah, dengan tekanan 200 mTorr, plasma yang muncul lebih sedikit dibandingkan dengan tekanan 100 mTorr. Dari citra SEM pada Gambar 4 terlihat bentukan wire namun dengan ukuran diameter sekitar 300$500 \mathrm{~nm}$, bisa dikatakan wire yang terbentuk adalah whisker belum menjadi nanowire.
Gambar 4: (a) dan (b) adalah Citra SEM penampang melintang Silikon wishker yang sama, pada penumbuhan tekanan 200 mTorr dengan titik fokus pengambilan citra yang berbeda.

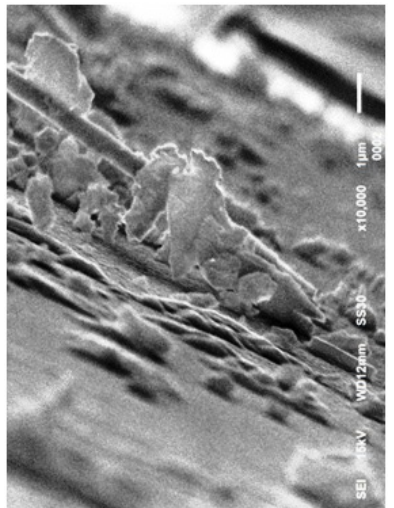

(a)

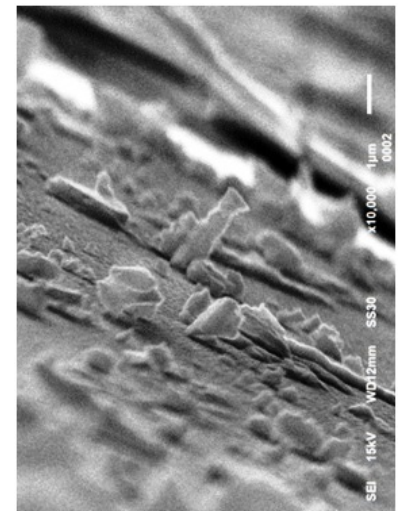

(b)
Gambar 5: (a) dan (b) adalah Citra SEM penampang melintang Silikon wishker dengan diameter wire lebih dari $500 \mathrm{~nm}$, pada penumbuhan tekanan200 mTorr dengan titik fokus pengambilan citra yang berbeda.

\section{Penumbuhan SiNW pada tekanan 300 mTorr}

Gambar 5 menunjukan penumbuhan SiNW yang dilakukan pada tekanan 300 mTorr. Sama halnya dengan hasil pada tekanan 200 mTorr, dari hasil citra SEM di peroleh bentuk wire berbentuk whisker dengan ukuran diameter wishker yang terbentuk lebih dari $500 \mathrm{~nm}$.

\section{Penumbuhan SiNW pada tekanan 400 mTorr}

Pada penumbuhan silikon nanowire dengan tekanan 400 mTorrtidak ditemukan bentukan whisker ataupun nanowire terlihat pada Gambar 7, hal tersebut menandakan bahwa pada tekanan 400 mTorr belum terjadi penumbuhan silikon nanowire, salah satu penyebabnya adalah semakin besar tekanan di dalam chamber akan menimbulkan efek turbulensi pada gas yang menyebabkan tidak terjadi bombardier elektron. 


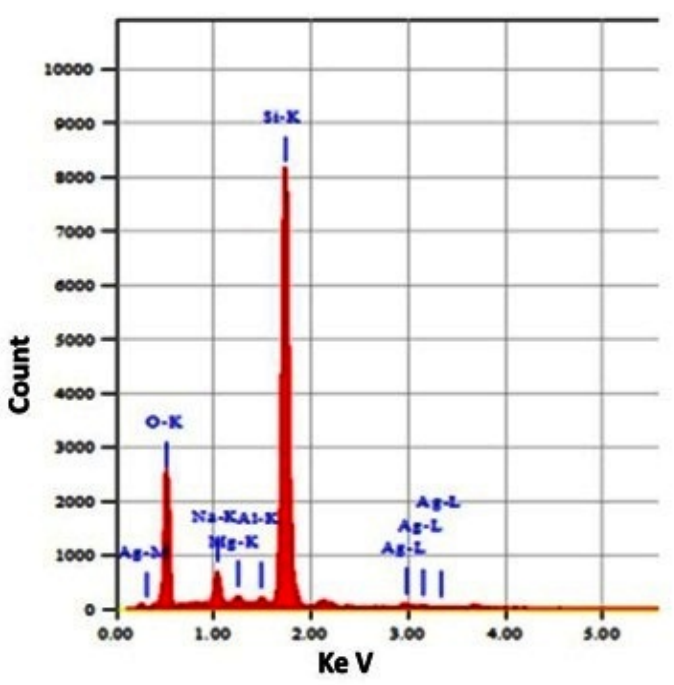

(a) $100 \mathrm{mTorr}$

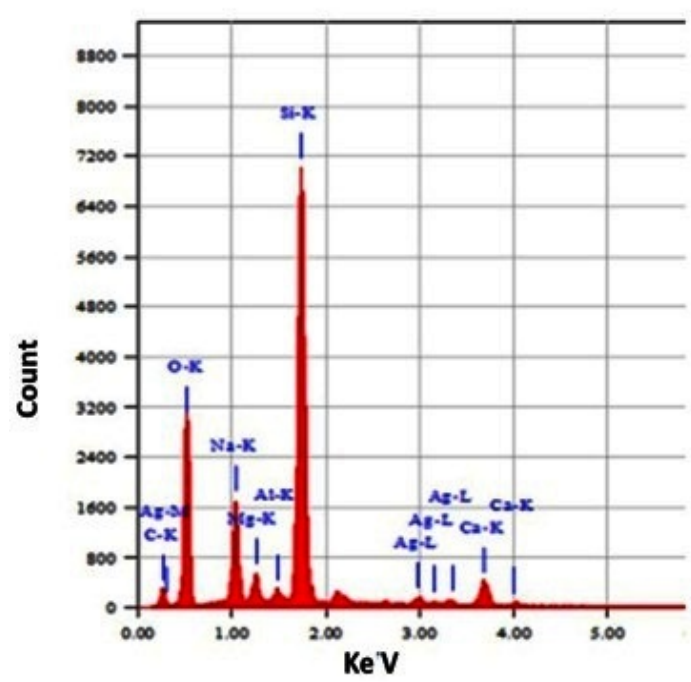

(c) $300 \mathrm{mTorr}$

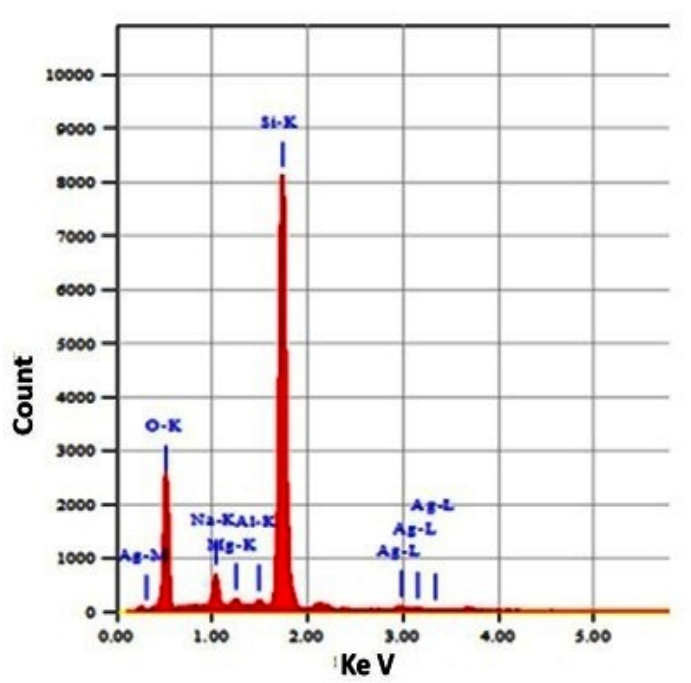

(b) $200 \mathrm{mTorr}$

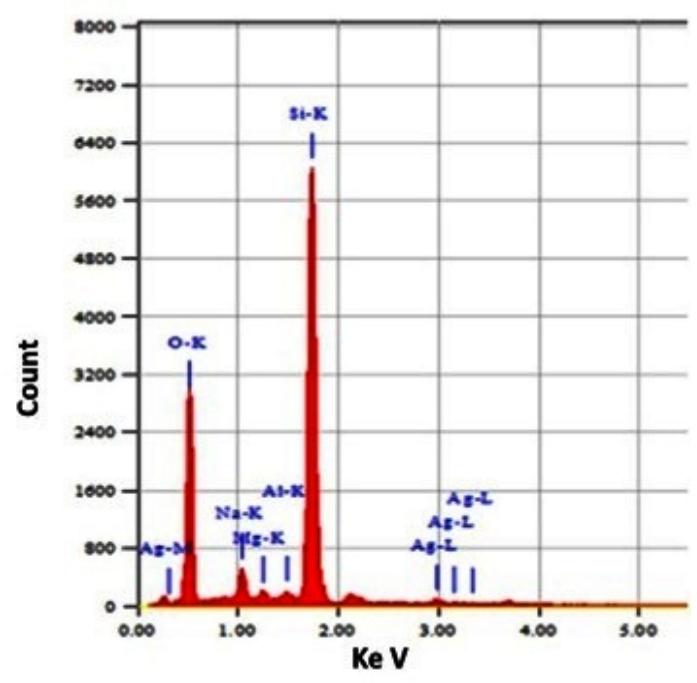

(d) 400 mTorr

Gambar 6: Spektrum EDX SiNW yang ditumbuhkan pada tekanan yang berbeda.

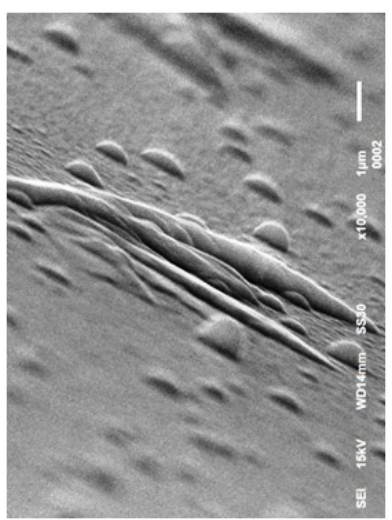

(a)

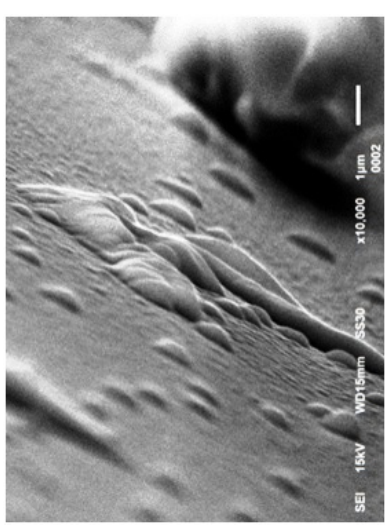

(b)
Gambar 7: Citra SEM penampang melintang substrat film/Ag yang ditumbuhkan pada tekanan 400 mTorr.

\section{Hasil karakterisasi EDX}

Karakterisasi EDX dilakukan untuk mengetahui komposisi kimia yang terdapat dalam sampel. EDX digunakan untuk menganalisa secara kuantitatif dari persentase masing-masing elemen. Karakterisasi ini hanya dapat dilakukan bersamaan dengan SEM.

Hasil analisis EDX ke-empat sampel ditunjukkan pada Gambar 6, dengan prosentase komposisi massa unsur-unsur seperti ditunjukkan Tabel I.

Tekanan deposisi mengindikasikan banyaknya jumlah gas di dalam chamber. Tekanan rendah berarti jumlah gas metan dalam chamber sedikit, demikian pula sebaliknya. Pada tekanan tinggi, jalan bebas rata-rata (mean free path) elektron akan mengecil sehingga medan listrik perlu dinaikkan untuk mempertahankan plasma.

Pada tekanan rendah dengan jumlah gas sedikit, jalan bebas 
TABEL I: Prosentase massa terhadap variasi tekanan gas.

\begin{tabular}{ccccc}
\hline \hline \multicolumn{4}{c}{ No Tekanan gas P rosentase massa (\%) } \\
& (mTorr) & $\mathrm{Ag}$ & $\mathrm{Si}$ & $\mathrm{O}$ \\
\hline 1 & 100 & 2,12 & 53,04 & 39,36 \\
2 & 200 & 1,97 & 45,34 & 47,63 \\
3 & 300 & 3,26 & 41,58 & 43,52 \\
4 & 400 & 4,32 & 34,02 & 38,64 \\
\hline \hline
\end{tabular}

rata-rata molekul gas meningkat sehingga gas dapat menyebar ke seluruh ruang chamber. Akibatnya ketika diberi daya rf, plasma yang muncul lebih banyak. Elektron memiliki energi yang lebih besar untuk bertumbukan dengan molekul-molekul gas. Dekomposisi gas menjadi atom-atom karbon pun menjadi lebih efektif. Sehingga dapat dikatakan bahwa untuk penumbuhan SiNW pada daya rf rendah (8 watt), penumbuhan SiNW pada tekanan 100 mTorr sangat efektif karena elektron mempunyai energi yang cukup untuk bertumbukan.

\section{SIMPULAN}

Pada penelitian ini penumbuhan lapisan tipis katalis perak yang berbentuk padatan sebagai pemandu penumbuhan silikon nanowire. Perak ditumbuhkan di atas substrat gelas objek $\left(\mathrm{A}-\mathrm{SiO}_{2}\right)$ dengan metode evaporasi lalu dilakukan annealing selama 1 jam dan menghasilkan island berukuran 70-80 nm. Penumbuhan silikon nanowire dilakukan dengan menggunakan metode HWC-inplasma-VHF PECVD dengan optimasi tekanan gas, 100 mTorr, 200 mTorr, 300 mTorr dan 400 mTorr. Berhasil diketahui hubungan parameter tekanan dengan penumbuhan silikon nanowire, pada tekanan 100 mTorr diperoleh rasio penumbuhan silikon nanowire terbanyak dengan diameter $70-150 \mathrm{~nm}$, sedangkan dengan tekanan 400 mTorr belum terjadi penumbuhan silikon nanowire dikarenakan tekanan gas yang cukup tinggi sehingga yang terbentuk masih island-island dari Ag.
[1] I. Usman, Fabrikasi Divais Sel Surya Berbasis $\mu c-$ Si:H dengan Teknik VHFPECVD, Magister Thesis, Institut Teknologi Bandung, Bandung, 2001.

[2] I.F. Suherman, Penumbuhan Lapisan Tipis Silikon Mikrokristalin Terhidrogenasi ( $\mu c-S i: H)$ dengan Metode Hot Wire Cell Very High Frequency PECVD, Undergraduate Thesis, Institut Teknologi Bandung, Bandung, 2011.

[3] M.W. Shao, D.D.D. Ma, and S.T. Lee, Eur. J. Inorg. Chem., 4264-4278 (2010).

[4] A.K. Wanekaya, et al., Electroanalysis, 18(6), 533-550 (2006).

[5] A. Setiawan, dkk., Sintesis Lapisan Tipis Au sebagai Katalis untuk Deposisi Silicon Nanowire, Prosiding Seminar Nasional
Fisika 2010, 251-257 (2010).

[6] J. Cervenka, et al., Nanotechnology, 21, 415604 (7pp) (2010).

[7] Y. Arryanto, dkk., Iptek Nano di Indonesia: Terobosan, Peluang, dan Strategi (Kemenristek, Jakarta, 2007).

[8] D. Wang, et al., Nano Letters, 4(5), 871-874 (2004).

[9] O'Donnell Benedict, et al., J. Non-Cryst. Solids, 358(17), 22992302 (2011)

[10] I. Usman, Penumbuhan Lapisan Tipis Silikon Amorf Terhidrogenasi dengan Teknik HWC-VHF-PECVD dan Aplikasinya pada Divais Sel Surya, Doctoral Thesis, Institut Teknologi Bandung, Bandung (2006). 